\title{
Cryoprotection of Day-4 mouse embryos by methanol
}

\author{
W. F. Rall*, Maria Czlonkowska†, Sheila C. Barton, and C. Polge \\ A.R.C. Institute of Animal Physiology, Animal Research Station, 307 Huntingdon Road, \\ Cambridge CB3 OJQ, U.K.
}

\begin{abstract}
Summary. Methanol was examined as a cryoprotective additive that permits the direct transfer of frozen-thawed Day-4 mouse embryos to foster mothers without dilution of the cryoprotectant. Methanol permeated the embryos rapidly, was not toxic and exerted a cryoprotective action. The highest level of survival $(50 \%)$ of embryos in vitro was observed after equilibration in Medium PB1 containing 3.0 M-methanol, slow cooling $\left(0.5^{\circ} \mathrm{C} / \mathrm{min}\right)$ to a temperature between -30 and $-40^{\circ} \mathrm{C}$, rapid cooling $\left(800^{\circ} \mathrm{C} / \mathrm{min}\right)$ and storage in liquid nitrogen $\left(-196^{\circ} \mathrm{C}\right)$, rapid warming $\left(800^{\circ} \mathrm{C} / \mathrm{min}\right)$, and rapid dilution. A high rate of development in vivo to late-stage fetuses (up to $81 \%$ ) was observed when cryopreserved embryos were transferred to pseudopregnant recipients immediately after thawing.
\end{abstract}

\section{Introduction}

The successful cryopreservation of mouse embryos depends on the presence of molar concentrations of a cryoprotective additive, such as dimethyl sulphoxide (DMSO) or glycerol, and slow cooling to temperatures below $-60^{\circ} \mathrm{C}$ combined with slow warming (Whittingham, Leibo \& Mazur, 1972; Wilmut, 1972; Leibo, Mazur \& Jackowski, 1974). Similar procedures have proved successful for other mammalian embryos and have led to important practical applications, namely the long-term storage and international transportation of laboratory and domestic animal embryos (Polge, 1978; Seidel, 1981; Zeilmaker, 1981). Later work has improved and simplified the cooling and warming procedures of the cryopreservation process, especially the development of cooling procedures that permit rapid warming (Willadsen, 1977; Whittingham, Wood, Farrant, Lee \& Halsey, 1979; Wood \& Farrant, 1980; Kasai, Niwa \& Iritani, 1980; Miyamoto \& Ishibashi, 1983).

One consequence of the presence of a permeating cryoprotective additive is the possibility of osmotic swelling and injury when thawed embryos are returned to normal physiological conditions. It is therefore generally accepted that the cryoprotectant must be carefully diluted from thawed embryos before transfer into the uteri of recipient animals (Leibo \& Mazur, 1978). Two methods are widely used to dilute cryoprotectants from embryos in suspensions. The first is to reduce the concentration of additive by a series of steps with intervening holding periods to permit equilibration (Whittingham et al., 1972; Wilmut, 1972). Mouse embryos in DMSO (1.5 M) will survive a rapid two-step dilution, however, if the temperature during dilution is $\geq 20^{\circ} \mathrm{C}$ (Whittingham et al., 1979). The second method is to transfer the embryos into saline containing a sufficiently high concentration of an impermeable solute, such as $0.9 \mathrm{M}$-sucrose, to counteract osmotic swelling (Leibo \& Mazur, 1978). After the efflux of intracellular additive, the embryos are returned to isotonic saline.

* Present address: American Red Cross Blood Services Laboratories, Cryobiology Laboratory, 9312 Old Georgetown Road, Bethesda, Maryland 20814, U.S.A.

$\dagger$ Present address: Institute of Genetics and Animal Breeding, Polish Academy of Sciences, 05-511 Mrokow, Poland. 
Procedures would be greatly simplified if embryos could be transferred to recipients immediately after thawing. A sucrose-dilution procedure has been developed which allows the freezing-thawing, post-thaw handling and non-surgical transfer of cattle embryos to be accomplished within a plastic insemination straw (Leibo, West \& Perry, 1982; Renard, Heyman \& Ozil, 1982). Another approach which might eliminate the handling of embryos after thawing would be to use a cryoprotective additive that did not require dilution. One such substance is methanol. In a variety of cell types, methanol enters and leaves the cell very rapidly (Collander, 1954; Wright \& Diamond, 1969; Naccache \& Sha'afi, 1973; Morris, 1980) and provides protection against the deleterious effects of freezing and thawing (Lovelock, 1954; Polge \& Soltys, 1960; Meryman, 1968; Rapatz, 1973; Ashwood-Smith \& Lough, 1975; James \& Farrant, 1977; Morris, Coulson \& Clarke, 1979; Morris, 1980; James, 1980; Harvey, Kelly \& Ashwood-Smith, 1982). The present experiments were designed to evaluate whether methanol would fulfil the necessary requirements for the direct transfer of cryopreserved Day-4 mouse embryos.

\section{Materials and Methods}

\section{Source of embryos}

Embryos were obtained from random bred MF1 (Ola: MF1) females that were superovulated and mated with F1 hybrid (C57BL/6J $\times$ CBA/Ca) males as described by Rall \& Polge (1984). On the morning of Day 4 ( $\sim 89 \mathrm{~h}$ after the hCG injection), embryos were flushed from the excised uteri with a modified Dulbecco's phosphate-buffered medium (PB1; Whittingham, 1974). After collection, the embryos were washed in fresh $\mathrm{PB} 1$, pooled and held at room temperature $\left(\sim 20^{\circ} \mathrm{C}\right)$ until used.

\section{Freezing and thawing}

Morulae and early cavitating blastocysts were transferred into a Petri dish of Medium PB1 containing methanol $(3.0 \mathrm{M})$ for $10-20 \mathrm{~min}$ at room temperature $\left(20-25^{\circ} \mathrm{C}\right)$. Between 15 and 30 embryos were then transferred into thin-walled glass test tubes $(50 \mathrm{~mm}$ long, $6.25 \mathrm{~mm}$ o.d., $4.75 \mathrm{~mm}$ i.d.) which contained $0.1 \mathrm{ml} \mathrm{3.0} \mathrm{M-methanol} \mathrm{in} \mathrm{Medium} \mathrm{PB1.} \mathrm{The} \mathrm{tubes} \mathrm{were} \mathrm{placed} \mathrm{in} \mathrm{the} \mathrm{chamber}$ of a programmed liquid $\mathrm{N}_{2}$-vapour freezing machine (Model R202, Planner, Sunbury-on-Thames, U.K.) that was precooled to $-10^{\circ} \mathrm{C}$. Ice formation was induced $5 \mathrm{~min}$ later by touching the outside of each tube just above the surface of the liquid with cold forceps. Samples were returned to the chamber and $6 \mathrm{~min}$ later, the chamber was cooled at $0.5^{\circ} \mathrm{C} / \mathrm{min}$. The temperature of 2 replicate tubes containing the suspending solution was continuously recorded using thermocouples. When the temperature of the replicate tubes had decreased to the appropriate temperature between -10 and $-60^{\circ} \mathrm{C}$, samples were removed from the chamber and immediately warmed rapidly in $+37^{\circ} \mathrm{C}$ water or immersed ('plunged') into liquid $\mathrm{N}_{2}$ (cooling rate: $\sim 800^{\circ} \mathrm{C} / \mathrm{min}$ ). Samples in liquid $\mathrm{N}_{2}$ were stored for periods between 1 day and 4 months and most were warmed rapidly $\left(\sim 800^{\circ} \mathrm{C} / \mathrm{min}\right)$ in $+37^{\circ} \mathrm{C}$ water. Some samples were warmed slowly $\left(\sim 2^{\circ} \mathrm{C} / \mathrm{min}\right)$ by transfer into stirred alcohol, initially at $-100^{\circ} \mathrm{C}$.

\section{Recovery of embryos from test tubes}

Thawed samples were handled in one of two ways. (a) Most samples were diluted rapidly at room temperature by the addition of $\sim 0.8 \mathrm{ml} \mathrm{PB} 1$ to the tubes. The contents of each tube were recovered by aspiration and transferred to a Petri dish. Each tube was then rinsed with $1 \mathrm{ml}$ PB1. (b) Embryos were recovered from some tubes without dilution of the methanol and these samples were handled as in (a) except that Medium PBl containing methanol (3.0 M) was used in each step. Approximately $95 \%$ of the embryos frozen were recovered by either procedure. 
Survival assays

In-vitro culture. After the experimental treatment, embryos were washed in fresh Medium PB1, placed in $20 \mu \mathrm{l}$ drops of BMOC-3 medium (Brinster, 1972) in the well of a microwell culture plate (Sterilin No. 310) under paraffin oil, and incubated at $37^{\circ} \mathrm{C}$ in an atmosphere of $5 \% \mathrm{CO}_{2}$ in air. Survival was defined as the percentage of recovered embryos that developed to the expanded blastocyst stage after $24 \mathrm{~h}$.

In-vivo development. Embryos in Medium PB1 or Medium PB1 containing methanol (3.0 M) were transferred into a single uterine horn of a Day-3 pseudopregnant female mated to a proven sterile male. Experimental embryos were transferred into the right uterine horn and in some experiments untreated (control) embryos in Medium PB1 were transferred into the left horn. Development was assessed at autopsy on Day 15 or 16.

\section{Cryomicroscopy}

After equilibration in Medium PB1 containing methanol $(3.0 \mathrm{M})$, the embryos were handled as described earlier (Rall, Reid \& Farrant, 1980; Rall, Reid \& Polge, 1984). Briefly, 10 embryos were placed in a small drop of the suspending medium on a 16-mm diameter No. 1 coverglass and immediately covered with another coverglass. Broken slivers of a No. 0 coverglass placed around the drop prevented the embryos from being crushed. The 'coverglass sandwich' was then placed on the temperature-controlled slide of a low-temperature microscope stage (Reid, 1978). The appearance of the embryos during cooling and warming was recorded on 35-mm film (Ilford HP5) and time-lapse videotape using phase-contrast optics.

\section{Results}

\section{Osmotic behaviour of embryos during rapid addition and removal of methanol}

When Day-4 mouse embryos were transferred into Medium PB1 containing methanol (3.0 M) at $\sim 0^{\circ} \mathrm{C}$ or room temperature, no visible change in the volume of the embryos was observed over a period of $180 \mathrm{~min}$. Similarly, no volume change was observed when the methanol was subsequently diluted about 100 -fold by transfer directly into Medium PB1 at $\sim 0^{\circ} \mathrm{C}$ or room temperature. These observations indicate that methanol permeates very rapidly and suggest that the cell membranes of the embryos have a high permeability coefficient and/or low reflection coefficient to methanol.

\section{Survival of embryos after equilibration in methanol}

The development in vitro of embryos after exposure for various periods to $3.0 \mathrm{M}$-methanol at room temperature and rapid dilution is shown in Table 1 . The ability of the embryos to develop to the expanded blastocyst stage was not impaired even after $180 \mathrm{~min}$ in methanol. Embryos in $4.0 \mathrm{M}$ methanol exhibited a significantly lower rate of development after $120 \mathrm{~min}$ or longer at room temperature $(60 / 124,5$ replicate experiments, $P=0.02, t$ test). In all subsequent experiments, therefore, $3 \cdot 0 \mathrm{M}$-methanol in Medium PB1 was used.

The ability of embryos to develop to late-stage fetuses after equilibration in methanol and direct transfer into the uteri of pseudopregnant recipients is shown in Table 2 . In this experiment embryos were transferred into Medium PB1 containing methanol $(3.0 \mathrm{M})$ at room temperature, held for periods up to $45 \mathrm{~min}$, and then 10 embryos were transferred directly into the right horn of each recipient. Five untreated (control) embryos in Medium PB1 were transferred into the left horn of each recipient. A high level of normal development was observed: $56 / 90(62 \%)$ of the embryos transferred in methanol to recipients maintaining pregnancy developed normally compared to $34 / 45(76 \%)$ of the untreated embryos. 
Table 1. Survival of Day-4 mouse embryos after exposure to $3.0 \mathrm{M}-\mathrm{methanol}$ at $\sim 20^{\circ} \mathrm{C}$ and rapid dilution

\begin{tabular}{ccc}
\hline $\begin{array}{c}\text { Time in methanol } \\
(\mathrm{min})\end{array}$ & $\begin{array}{c}\text { Total no. of embryos } \\
\text { (no. of replicates) }\end{array}$ & $\begin{array}{c}\text { Expanded blastocysts after } \\
24 \mathrm{~h} \text { in culture }(\%)\end{array}$ \\
\hline 30 & $86(5)$ & $85(99)$ \\
60 & $102(5)$ & $99(97)$ \\
90 & $102(5)$ & $96(94)$ \\
120 & $127(6)$ & $120(95)$ \\
180 & $117(5)$ & $114(97)$ \\
Control & $62(5)$ & $57(92)$ \\
\hline
\end{tabular}

Table 2. In-vivo development of Day-4 mouse embryos transferred in 3.0 M-methanol directly into uteri of recipients

\begin{tabular}{lcccc}
\hline Treatment & $\begin{array}{c}\text { Total no. of } \\
\text { embryos transferred } \\
\text { (no. of recipients) }\end{array}$ & $\begin{array}{c}\text { No. of recipients } \\
\text { maintaining pregnancy } \\
\text { (total no. of embryos transferred) }\end{array}$ & $\begin{array}{c}\text { No. of } \\
\text { implantations* } \\
(\%)\end{array}$ & $\begin{array}{c}\text { No. of } \\
\text { normal fetuses* } \\
(\%)\end{array}$ \\
\hline $3 \cdot 0$ M-Methanol & $120(12)$ & $9(90)$ & $68(76)$ & $56(62)$ \\
Control & $60(12)$ & $9(45)$ & $38(84)$ & $34(76)$ \\
\hline
\end{tabular}

*At autopsy on Day 16 of pregnancy.

\section{Freeze-thaw sensitivity}

Embryos in $3.0 \mathrm{M}$-methanol were cooled slowly $\left(0.5^{\circ} \mathrm{C} / \mathrm{min}\right)$ to various temperatures between -10 and $-60^{\circ} \mathrm{C}$ and then either immediately warmed rapidly or transferred directly into liquid $\mathrm{N}_{2}$ before rapid warming (see Text-fig. 1, insert diagram). Survival, based on in-vitro culture, is shown in Text-fig. 1. When embryos were warmed immediately after slow cooling, a high level of survival $(78-98 \%)$ was observed as long as slow cooling was terminated before the temperature reached $-45^{\circ} \mathrm{C}$. Slow cooling to $-45^{\circ} \mathrm{C}$ or below, however, led to a rapid decrease in survival. When embryos were transferred into liquid $\mathrm{N}_{2}$ after slow cooling, the highest level of survival $(50 \%)$ was obtained when slow cooling was terminated at $-35^{\circ} \mathrm{C}$. Lower or no survival resulted when samples were transferred into liquid $\mathrm{N}_{2}$ at higher or lower temperatures.

The survival of embryos warmed slowly $\left(2^{\circ} \mathrm{C} / \mathrm{min}\right)$ after slow cooling to -35 or $-60^{\circ} \mathrm{C}$ and transfer into liquid $\mathrm{N}_{2}$ was also examined (4 replicate samples of a total of 100 and 99 embryos, respectively). None of these embryos survived.

\section{Cryomicroscopy}

The appearance of 5 morulae during slow cooling $\left(0 \cdot 5^{\circ} \mathrm{C} / \mathrm{min}\right)$ to $-38^{\circ} \mathrm{C}$ and subsequent slow warming $\left(5^{\circ} \mathrm{C} / \mathrm{min}\right)$ in methanol is shown in Plate 1 . The first event observed during cooling was the appearance of extracellular ice crystals at $-8^{\circ} \mathrm{C}$ (Pl. 1, Fig. 2). The embryos were gently pushed and/or rotated as the ice grew (compare P1. 1, Figs $1 \& 3$ ). With continued slow cooling, the embryos gradually shrank and became increasingly obscured by the extracellular ice (Pl. 1, Figs 3-6). When the temperature reached $-38^{\circ} \mathrm{C}\left(\mathrm{Pl}\right.$. 1, Fig. 6), the embryos were immediately warmed at $5^{\circ} \mathrm{C} / \mathrm{min}$ (P1. 1, Figs 7-12). During slow warming there was a slight swelling of the embryos as the temperature increased to the melting point $\left(-8^{\circ} \mathrm{C}, \mathrm{Pl}\right.$. 1, Fig. 10). However, most of the swelling of the embryos back to their initial volume occurred after thawing (Pl. 1, compare Figs 10, $11 \& 12$ ). By 10-15 min after the dissolution of ice, the embryos had returned to their initial volume. Approximately $15 \mathrm{~min}$ after the photograph shown in Pl. 1, Fig. 12, the embryos were recovered 

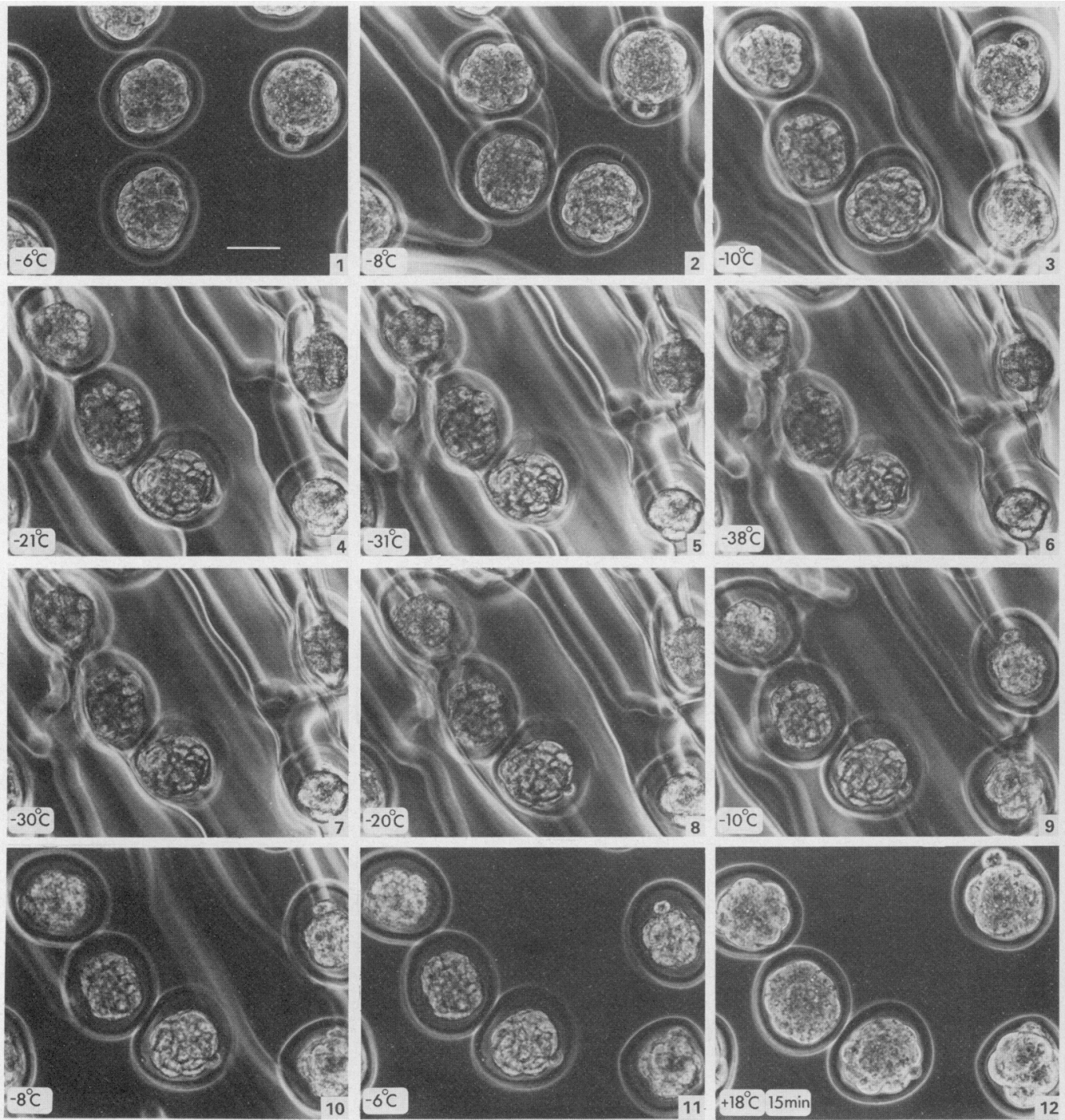

Microscopical appearance of 5 mouse morulae in $3.0 \mathrm{M}$ methanol during slow cooling to $-38^{\circ} \mathrm{C}$ and slow warming. The morulae were cooled at $0.5^{\circ} \mathrm{C} / \mathrm{min}$ from +5 to $-38^{\circ} \mathrm{C}$ and Figs $1-6$ were taken at the temperatures indicated. When $-38^{\circ} \mathrm{C}$ was reached, the morulae were warmed at $5^{\circ} \mathrm{C} / \mathrm{min}$ to $+18^{\circ} \mathrm{C}$ (Figs $7-12$ ). The scale bar represents approximately $50 \mu \mathrm{m}$. See text for details. 

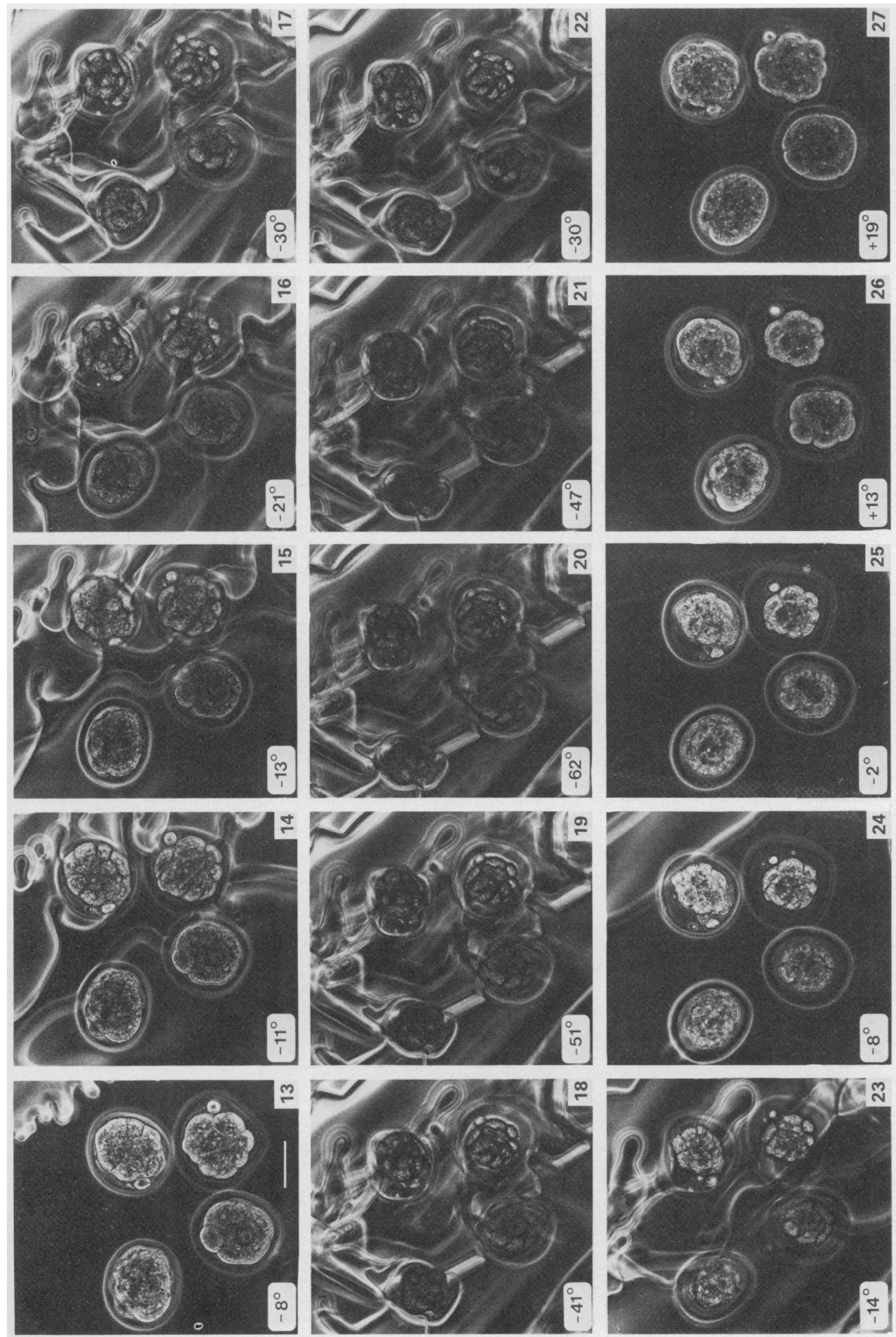


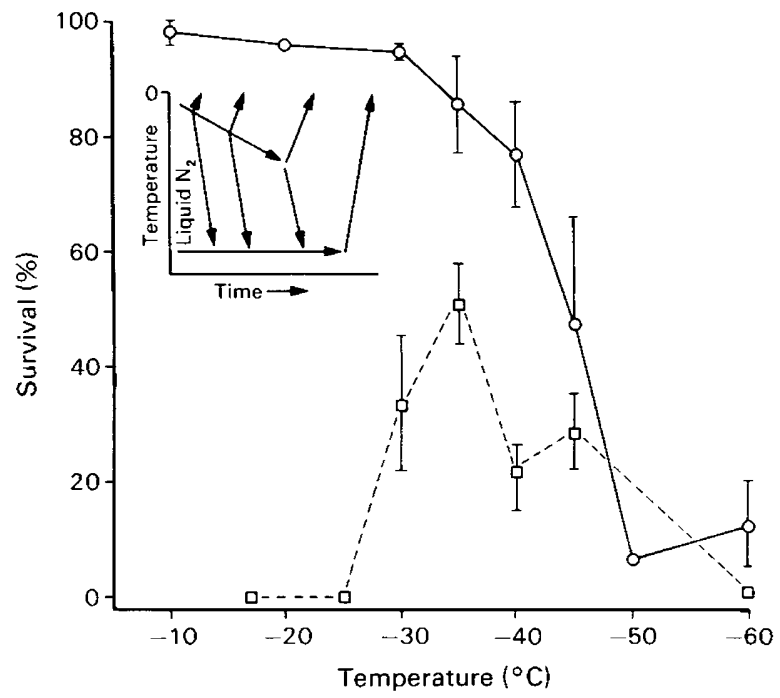

Text-fig. 1. In-vitro survival of Day-4 mouse embryos after slow cooling $\left(0.5^{\circ} \mathrm{C} / \mathrm{min}\right)$ in $3.0 \mathrm{M}$ methanol to various temperatures between -10 and $-60^{\circ} \mathrm{C}$ before rapid warming $\left(\sim 800^{\circ} \mathrm{C} / \mathrm{min}, O\right)$ or rapid cooling $\left(\sim 800^{\circ} \mathrm{C} / \mathrm{min}\right)$ in liquid $\mathrm{N}_{2}$ and rapid warming $\left(\sim 800^{\circ} \mathrm{C} / \mathrm{min}, \square\right)$. Values are means \pm s.e.m. The number of replicate samples and total number of embryos recovered after thawing (in parentheses) for each curve, starting with samples warmed rapidly $(O)$ from $-10^{\circ} \mathrm{C}$, were $2(44), 1(25), 3(71), 4(75), 4(86), 4(85), 1(15)$ and $6(138)$; and samples transferred into liquid $\mathrm{N}_{2}(\square)$ from $-17^{\circ} \mathrm{C}$, were $1(15), 2(37), 6$ (124), 9 (194), 6 (143), 4 (104) and 4 (103).

from the cryomicroscope stage, diluted rapidly out of the methanol, and then placed into culture. All of the embryos had developed to the expanded blastocyst stage when examined $24 \mathrm{~h}$ later.

The appearance of 4 morulae during slow cooling $\left(0.5^{\circ} \mathrm{C} / \mathrm{min}\right)$ to $-62^{\circ} \mathrm{C}$ and subsequent slow warming $\left(5^{\circ} \mathrm{C} / \mathrm{min}\right)$ in methanol is shown in Plate 2. Extracellular ice first appeared during cooling at $-8^{\circ} \mathrm{C}$ (P1. 2, Fig. 13). During continued slow cooling the embryos gradually shrank and became increasingly obscured as the extracellular ice grew (P1. 2, Figs 14-20). At temperatures below $-35^{\circ} \mathrm{C}$, the cytoplasm and extracellular ice gradually darkened. When the temperature reached $-62^{\circ} \mathrm{C}$, the embryos were immediately warmed at $5^{\circ} \mathrm{C} / \mathrm{min}$ (Pl. 2, Figs 21-27). During slow warming little swelling of the embryos was observed until the extracellular ice melted (P1. 2, Fig. 24). Then the embryos swelled until they completely filled the perivitelline space (P1. 2, Figs 25-27). Approximately 10 min after the photograph shown in Pl. 2, Fig. 27, the embryos were recovered from the cryomicroscope stage, diluted rapidly, and placed into culture. All of the embryos were degenerate when examined $24 \mathrm{~h}$ later.

\section{In-vivo development of frozen-thawed embryos}

The developmental potential of embryos frozen in methanol was assessed by transfer to pseudopregnant recipients. In these experiments, embryos were segregated into groups of morulae

\section{PLATE 2}

Microscopical appearance of 4 mouse morulae in $3.0 \mathrm{M}-$ methanol during slow cooling to $-62^{\circ} \mathrm{C}$ and slow warming. The morulae were cooled at $0.5^{\circ} \mathrm{C} / \mathrm{min}$ from +5 to $-62^{\circ} \mathrm{C}$ and Figs $13-20$ were taken at the temperatures indicated. When $-62^{\circ} \mathrm{C}$ was reached, the morulae were warmed at $5^{\circ} \mathrm{C} / \mathrm{min}$ to $+19^{\circ} \mathrm{C}$ (Figs $21-27$ ). The scale bar represents approximately $50 \mu \mathrm{m}$. See text for details. 
and early cavitating blastocysts and frozen separately. In the first experiment, frozen-thawed embryos were diluted rapidly and cultured overnight. Only those embryos that developed to the blastocyst stage were transferred into the uteri of pseudopregnant recipients (Table 3 ).

Table 3. In-vivo development of Day-4 mouse embryos frozen-thawed in 3.0 M-methanol and cultured for $12-15 \mathrm{~h}$ before transfer

\begin{tabular}{lcccc}
\hline $\begin{array}{c}\text { Embryo stage frozen } \\
\text { ("plunge' temp.) }\end{array}$ & $\begin{array}{c}\text { No. of blastocysts } \\
\text { transferred*/no. frozen }\end{array}$ & $\begin{array}{c}\text { No. of } \\
\text { implantations (\%) } \dagger\end{array}$ & $\begin{array}{c}\text { No. of } \\
\text { normal fetuses (\%) } \dagger\end{array}$ & $\begin{array}{c}\text { Overall } \\
\text { survival } \ddagger\end{array}$ \\
\hline Morula $\left(-35^{\circ} \mathrm{C}\right)$ & $15 / 30$ & $13(87)$ & $12(80)$ & $40 \%$ \\
Early blastocysts $\left(-30^{\circ} \mathrm{C}\right)$ & $9 / 29$ & $7(78)$ & $4(44)$ & $14 \%$ \\
Early blastocysts $\left(-35^{\circ} \mathrm{C}\right)$ & $13 / 28$ & $7(54)$ & $7(54)$ & $25 \%$ \\
\hline
\end{tabular}

* Only blastocysts with normal morphology after culture were transferred into the uterus of a recipient on Day 3 of pseudopregnancy.

$\dagger$ At autopsy on Day 15 of pregnancy.

$\ddagger$ Based on no. of embryos frozen.

In the second experiment, embryos were transferred into the uteri of recipients immediately after thawing without dilution of the methanol (Table 4). The highest level of normal in-vivo development $(81 \%)$ was observed for morulae that were cooled slowly to $-30^{\circ} \mathrm{C}$ and then plunged into liquid $\mathrm{N}_{2}$. Lower levels of normal development were observed when embryos were plunged from $-35^{\circ} \mathrm{C}$.

Table 4. In-vivo development of Day-4 mouse embryos frozen-thawed in 3.0 M-methanol and immediately transferred into recipients

\begin{tabular}{lcccc}
\hline $\begin{array}{c}\text { Embryo stage frozen } \\
\text { ('plunge' temp.) }\end{array}$ & $\begin{array}{c}\text { Total no. of } \\
\text { embryos transferred* } \\
\text { (no. of recipients) }\end{array}$ & $\begin{array}{c}\text { Recipients } \\
\text { maintaining } \\
\text { pregnancy }\end{array}$ & $\begin{array}{c}\text { No. of } \\
\text { implantations } \dagger \\
(\%)\end{array}$ & $\begin{array}{c}\text { No. of } \\
\text { normal fetuses } \dagger \\
(\%)\end{array}$ \\
\hline Morula $\left(-30^{\circ} \mathrm{C}\right)$ & $21(2)$ & 2 & $18(86)$ & $17(81)$ \\
Morula $\left(-35^{\circ} \mathrm{C}\right)$ & $21(2)$ & 2 & $13(62)$ & $6(29)$ \\
Early blastocysts $\left(-35^{\circ} \mathrm{C}\right)$ & $48(4)$ & 3 & $17(35)$ & $5(11)$ \\
Early blastocysts $\left(-40^{\circ} \mathrm{C}\right)$ & $20(2)$ & $\mathbf{0}$ & - & - \\
\hline
\end{tabular}

* All embryos recovered after thawing were transferred directly into the uterus of a recipient on Day 3 of pseudopregnancy (no dilution of methanol).

$\uparrow$ At autopsy on Day 15 of pregnancy.

\section{Discussion}

These results show that methanol satisfies the requirements for use as a cryoprotectant which permits the direct transfer of embryos after thawing without dilution. First, methanol permeates embryos very rapidly without visible shrinkage on addition or swelling on dilution. Secondly, methanol is non-toxic to the subsequent development of embryos: exposure to $3.0 \mathrm{M}$-methanol for $3 \mathrm{~h}$ at room temperature did not decrease the subsequent in-vitro development to the expanded blastocyst stage. Thirdly, embryos in $3.0 \mathrm{M}$-methanol can be transferred directly into the uterus of a foster mother with no ill effects on the recipient or the development of the embryos. Fourth, when the appropriate freezing/thawing conditions are used, embryos will exhibit a high rate of in-vitro development. Finally, we have demonstrated that embryos frozen in methanol $(3.0 \mathrm{M})$ and stored in liquid $\mathrm{N}_{2}$ are capable of developing to normal late-stage fetuses when transferred directly after rapid thawing into the uterus of pseudopregnant recipients. 
Methanol has long been known to provide protection against the deleterious effects of freezing and thawing (Lovelock, 1954). The mechanism by which methanol protects against injury during slow freezing is thought to be related to its colligative properties of reducing the increase in the concentration of salts in the unfrozen portion of the suspending solution and perhaps of increasing the fraction of the extracellular solution that remains unfrozen at any given subzero temperature (Lovelock, 1953; Mazur, Rall \& Rigopoulos, 1981). Morris (1980) has suggested that the high permeability of methanol, particularly at sub-zero temperatures, may also provide protection. According to this view, methanol can move into and out of the cytoplasm during freezing and thawing and reduce the extent of cellular shrinkage. Our cryomicroscope observations (Plates 1 \& 2), however, indicate that morulae frozen slowly in methanol shrink to about half their initial volume by about $-40^{\circ} \mathrm{C}$. A similar osmotic behaviour has been reported for ova and embryos frozen slowly in the presence of DMSO or glycerol (Leibo, 1977; Rall et al., 1984; Lehn-Jensen \& Rall, 1983).

The survival of embryos frozen in methanol shows a critical dependence on the cooling conditions (see Text-fig. 1). High survival is obtained after slow cooling but only when warming is started before the temperature reaches $-45^{\circ} \mathrm{C}$. When slow cooling is continued to temperatures below $-45^{\circ} \mathrm{C}$, methanol ceases to protect against injury. This injury may be a consequence of an increase in the concentration of methanol to toxic levels as ice continues to form in the residual unfrozen solution ('chemical toxicity'; Lovelock, 1954) or of the inability of the embryos to shrink to the extent required for osmotic equilibration (Meryman, 1968). Our cryomicroscopical observations may provide additional insight into the mechanisms of slow freezing injury. Embryo death may be related in some unknown way to the observed gradual darkening of the embryos when slow cooling is continued below $\sim-35^{\circ} \mathrm{C}$ (see Plate 2). This darkening probably results from a microscopical artefact associated with the relatively low increase in the index of refraction of methanol solutions as they become concentrated (Wolf, Brown \& Prentiss, 1982). Therefore as the concentration of the residual extracellular solution and cytoplasm increases during slow cooling, the phase-contrast image decreases as the index of refraction of the cytoplasm approaches that of the surrounding liquid. Indeed, embryos frozen similarly in DMSO or glycerol are not injured and do not exhibit a darkened appearance (W. F. Rall, unpublished observations).

Regardless of the precise mechanism responsible for slow freezing injury, we have found that embryos in methanol will survive long-term storage in liquid $\mathrm{N}_{2}$ provided that slow cooling is terminated between -30 and $-40^{\circ} \mathrm{C}$ and followed by rapid cooling (and rapid warming). The protective action of rapid cooling is probably related to the ability of the concentrated cytoplasm and residual extracellular liquid to supercool and form a metastable glass, as shown for embryos frozen by similar procedures in the presence of DMSO or glycerol (Rall et al., 1980; Rall et al., 1984). The rate of rapid cooling in liquid $N_{2}$ may be critical for successful preservation in methanol. Embryos cooled at the highest attainable rate on our cryomicroscope $\left(\sim 250^{\circ} \mathrm{C} / \mathrm{min}\right)$ after slow cooling $\left(0 \cdot 5^{\circ} \mathrm{C} / \mathrm{min}\right)$ to $-40^{\circ} \mathrm{C}$ exhibited a blackening ('flashing') characteristic of the formation of intracellular ice (Rall, Mazur \& McGrath, 1983) and the growth of small ice crystals in the residual liquid between the large extracellular ice crystals. None of these embryos developed in culture when assessed after rapid warming $\left(\sim 250^{\circ} \mathrm{C} / \mathrm{min}\right)$. Furthermore, the death of embryos warmed slowly after slow cooling to $-35^{\circ} \mathrm{C}$ and transfer into liquid $\mathrm{N}_{2}$ can be explained in terms of the devitrification (crystallization) of the glassy cytoplasm during warming (e.g. Rall et al., 1984). In the present study, we ensured high rates of rapid cooling and warming by using thin-walled glass test tubes and small sample volumes $(0.1 \mathrm{ml})$.

In conclusion, methanol shows promise for use as a cryoprotectant for mammalian embryos because the necessity of dilution before transfer into foster mothers is eliminated. However, further work is required to optimize the various conditions of the cryopreservation process.

W.F.R. was supported by a Fellowship from the Stanley Thomas Johnson Foundation. M.C. was supported by a Royal Society Visiting Scholarship. 


\section{References}

Ashwood-Smith, M.J. \& Lough, P. (1975) Cryoprotection of mammalian cells in tissue culture with methanol. Cryobiology 12, 517-518.

Brinster, R.L. (1972) Cultivation of the mammalian embryo. In Growth, Nutrition, and Metabolism of Cells in Culture, Vol. II, pp. 251-286. Eds G. H. Rothblat \& V. J. Cristofalo. Academic Press, New York.

Collander, R. (1954) The permeability of Nitella cells to non-electrolytes. Physiol. Plant. 7, 420-445.

Harvey, B., Kelly, R.N. \& Ashwood-Smith, M.J. (1982) Cryopreservation of zebra fish spermatozoa using methanol. Can. J. Zool. 60, 1867-1870.

James, E.R. (1980) Cryopreservation of Schistosoma mansoni Schistosomula using $40 \% \mathrm{v} / \mathrm{v}(10 \mathrm{M})$ methanol and rapid cooling. Cryo-Letters 1, 535-544.

James, E.R. \& Farrant, J. (1977) Recovery of infective Schistosoma mansoni Schistosomula from liquid nitrogen: A step towards storage of a live Schistosomiasis vaccine. Trans. R. Soc. trop. Med. Hyg. 71, 498-500.

Kasai, M., Niwa, K. \& Iritani, A. (1980) Survival of mouse embryos frozen and thawed rapidly. $J$. Reprod. Fert. $59,51-56$.

Lehn-Jensen, H. \& Rall, W.F. (1983) Cryomicroscopic observations of cattle embryos during freezing and thawing. Theriogenology 19, 263-277.

Leibo, S.P. (1977) Fundamental cryobiology of mouse ova and embryos. In The Freezing of Mammalian Embryos (Ciba Fdn Symp. No. 52), pp. 69-92. Eds K. Elliott \& J. Whelan. Elsevier, Amsterdam.

Leibo, S.P. \& Mazur, P. (1978) Methods for the preservation of mammalian embryos by freezing. In Methods in Mammalian Reproduction, pp. 179-201. Ed. J. Daniels, Jr. Academic Press, New York.

Leibo, S.P., Mazur, P. \& Jackowski, S.C. (1974) Factors affecting survival of mouse embryos during freezing and thawing. Expl Cell Res. 89, 79-88.

Leibo, S.P., West, A.W., III, \& Perry, B. (1982) A onestep method for direct nonsurgical transfer of frozenthawed bovine embryos. I. Basic studies. Cryobiology 19, 673-674 Abstr.

Lovelock, J.E. (1953) The haemolysis of human red blood cells by freezing and thawing. Biochim. Biophys. Acta 10, 415-426.

Lovelock, J.E. (1954) The protective action of neutral solutes against haemolysis by freezing and thawing. Biochem. J. 56, 265-270.

Mazur, P., Rall, W.F. \& Rigopoulos, N. (1981) Relative contributions of the fraction of unfrozen water and of salt concentration to the survival of slowly frozen human erythrocytes. Biophys. J. 36, 653-675.

Meryman, H.T. (1968) Modified model for the mechanism of freezing injury in erythrocytes. Nature, Lond. 218, 333-336.

Miyamoto, H. \& Ishibashi, T. (1983) Solid $\mathrm{CO}_{2}$ freezing of mouse embryos. J. Reprod. Fert. 67, 107-111

Morris, G.J. (1980) Plant cells. In Low Temperature Preservation in Medicine and Biology, pp. 253-283. Eds M. J. Ashwood-Smith \& J. Farrant. Pitman Medical, Tunbridge Wells.

Morris, G.J., Coulson, G. \& Clarke, A. (1979) The cryopreservation of Chlamydomonas. Cryobiology 16, $401-410$.

Naccache, P. \& Sha'afi, R.I. (1973) Patterns of nonelectrolyte permeability in human red blood cell membrane. J. gen. Physiol. 62, 714-736.
Polge, C. (1978) Embryo transfer and embryo preservation. Symp. zool. Soc. Lond. 43, 303-316.

Polge, C. \& Soltys, M.A. (1960) Protective action of some neutral solutes during the freezing of bull spermatozoa and trypanosomes. In Recent Research in Freezing and Drying, pp. 87-100. Eds A. S. Parkes \& A. U. Smith. Blackwell Scientific, Oxford.

Rall, W.F. \& Polge, C. (1984) Effect of warming rate on mouse embryos frozen and thawed in glycerol. $J$. Reprod. Fert. 70, 285-292.

Rall, W.F., Reid, D.S. \& Farrant, J. (1980) Innocuous biological freezing during warming. Nature, Lond. 286, 511-514.

Rall, W.F., Mazur, P. \& McGrath, J.J. (1983) Depression of the ice-nucleation temperature of rapidly cooled mouse embryos by glycerol and dimethyl sulfoxide. Biophys. J. 41, 1-12.

Rall, W.F., Reid, D.S. \& Polge, C. (1984) Analysis of slow-warming injury of mouse embryos by cryomicroscopical and physio-chemical methods. Cryobiology 21, (in press).

Rapatz, G. (1973) Cryoprotective effect of methanol during cooling of frog hearts. Cryobiology 10, 181184.

Reid, D.S. (1978) A programmed controlled temperature microscope stage. J. Microscopy 114, 241-248.

Renard, J.P., Heyman, Y. \& Ozil, J.P. (1982) Congélation de l'embryon bovin: une nouvelle méthode de décongélation pour le transfert cervical d'embryons conditionnés une seule fois en paillettes. Annls Med. vet. 126, 23-32.

Seidel, G.E. (1981) Superovulation and embryo transfer in cattle. Science, N.Y. 211, 351-358.

Whittingham, D.G. (1974) Embryo banks in the future of developmental genetics. Genetics, Princeton 78, 395402.

Whittingham, D.G., Leibo, S.P. \& Mazur, P. (1972) Survival of mouse embryos frozen to $-196^{\circ}$ and $-269^{\circ} \mathrm{C}$. Science, N.Y. 178, $411-414$.

Whittingham, D.G., Wood, M.J., Farrant, J., Lee, H. \& Halsey, J.D. (1979) Survival of frozen mouse embryos after rapid thawing from $-196^{\circ} \mathrm{C}$. J. Reprod. Fert. 56, 11-21.

Willadsen, S.M. (1977) Factors affecting the survival of sheep embryos during deep-freezing and thawing. In The Freezing of Mammalian Embryos (Ciba Fdn Symp. No. 52), pp. 175-201. Eds K. Elliott \& J. Whelan. Elsevier/North Holland, Amsterdam.

Wilmut, I. (1972) The effect of cooling rate, warming rate, cryoprotective agent, and stage of development on survival of mouse embryos during freezing and thawing. Life Sci. 11, 1071-1079.

Wolf, A.U., Brown, M.G. \& Prentiss, P.G. (1982) Concentrative properties of aqueous solutions. In Handbook of Chemistry and Physics, 63rd edn, p. D227. Ed. R. C. Weast. The Chemical Rubber Co., Cleveland.

Wood, M.J. \& Farrant, J. (1980) Preservation of mouse embryos by two-step freezing. Cryobiology 17, 178180.

Wright, E.M. \& Diamond, J.M. (1969) Patterns of nonelectrolyte permeability. Proc. R. Soc. B 172, 227271.

Zeilmaker, G.H. (Ed.) (1981) Frozen Storage of Laboratory Animals. Gustav Fischer, Stuttgart, 